\title{
ОКРЕМІ ПИТАННЯ НОРМАТИВНО-ПРАВОВОГО ЗАБЕЗПЕЧЕННЯ ПРОТИДІЇ ОРГАНІЗОВАНІЙ ЗЛОЧИННОСТІ В УКРАЇНІ
}

Наукова стаття присвячена аналізу окремих законодавчих актів, зокрема Закона України «Про організаційно-правові основи боротьби з організованою злочинністю" і Кримінального кодекса України, щодо регулювання питань протидії організованій злочинності в Україні.

Визначено, що важливою передумовою забезпечення ефективної протидії організованій злочинності $\epsilon$ cmворення ефективної (дієвої) нормативно-правової бази, визначення чіткої системи уповноважених суб'єктів здійснення такої протидії, мети і завдань їхньої діяльності, наділення необхідними повноваженнями і компетенцією, створення матеріально-технічних умов, ефективного кадрового забезпечення тощо.

Підкреслено, що проблемам ефективності правового регулювання приділялась увага завжди, але єдності в поглядах на зміст, структуру та критерії його ефективності не існує, особливо з питань протидії організованій злочинності.

Зазначено, що нині система нормативно-правових актів із протидії організованій злочинності є досить розгалуженою, куди входять норми конституційного, адміністративного, кримінального, кримінально-процесуального й інших галузей права. Незважаючи на те, що протидія організованій злочинності регулюється нормами різних галузей права і вони $\epsilon$ досить важливими, перевага серед усіх цих норм віддається адміністративно-правовим нормам протидії організованій злочинності, оскільки вони становлять більшість серед інших правових норм $і$ безпосередньо стосуються адміністративної (управлінської) діяльності, від якої залежать державна політика, стратегія, тактика, комплексність нормативно-правового регулювання й інші необхідні заходи щодо протидії організованій злочинності.

Звернута увага на застарілість і малу ефективність сьогодні чинного Закону України «Про організаційно-правові основи боротьби з організованою злочинністю» $і$ Кримінального кодексу України щодо регулювання питань протидії організованій злочинності в Україні.

Обгрунтовується ухвалення нового Закону України «Про протидію організованій злочинності» та потреба в активізації системного підходу до вирішення питань із протидіі організованій злочинності, з урахуванням тенденцій розвитку організованої злочинності.

Ключові слова: нормативно-правове забезпечення, організована злочинність.

Научная статья посвящена анализу отдельных законодательных актов, в частности Закона Украины «Об организационно-правовых основах борьбы с организованной преступностью» и Уголовного кодекса Украины, относительно регулирования вопросов противодействия организованной преступности в Украине.

Определено, что важной предпосылкой обеспечения эффективного противодействия организованной преступности является создание эффективной (действенной) нормативно-правовой базы, определение четкой системы уполномоченных субъектов осуществления такого противодействия, целей и задач их деятельности, наделение необходимыми полномочиями и компетенцией, создание материально-технических условий, эффективного кадрового обеспечения и др.

Подчеркнуто, что проблемам эффективности правового регулирования уделялось внимание всегда, но единства во взглядах на содержание, структуру и критерии его эффективности не существует, особенно по вопросам противодействия организованной преступности.

Отмечено, что сегодня система нормативно-правовых актов относительно противодействия организованной преступности достаточно разветвленная, куда входят нормы конституционного, административного, уголовного, уголовно-процессуального и других отраслей права. Несмотря на то, что противодействие организованной преступности регулируется нормами различных отраслей права и они являются достаточно важными, приоритетными считаются административно-правовые нормы противодействия организованной преступности, поскольку они составляют большинство среди других правовых норм и непосредственно касаются административной (управленческой) деятельности, от которой зависят государственная политика, стратегия, тактика, комплексность нормативно-правового регулирования и другие необходимые меры противодействия организованной преступности.

Обращено внимание на устарелость и малую эффективность сегодня действующего Закона Украины «Об организационно-правовых основах борьбы с организованной преступностью» и Уголовного кодекса Украины относительно регулирования вопросов противодействия организованной преступности в Украине.

Обосновываются принятие нового Закона Украины «O противодействии организованной преступности» и необходимость активизации системного подхода к решению вопросов по противодействию организованной преступности, с учетом тенденций развития организованной преступности.

Ключевые слова: нормативно-правовое обеспечение, организованная преступность.

Dotsenko O. S. Some issues of legal support for combating organized crime in Ukraine

The scientific article is devoted to the analysis of separate legislative acts, in particular: the Law of Ukraine "About organizational and legal bases of fight against organized crime" and the Criminal code of Ukraine concerning regulation of questions of counteraction to organized crime in Ukraine.

It is determined that an important prerequisite for ensuring effective anti-organization of organized crime is to create an effective (effective) legal regulatory framework, determining a clear system of authorized subjects of such a counteraction, purpose and objectives of their activities, providing the necessary powers and competence, the creation of material and technical conditions, effective personnel support, etc.

It is emphasized that the problems of the effectiveness of legal regulation have always been paid attention to, but 
there is no unity of views on the content, structure and criteria for assessing its effectiveness, especially on combating organized crime.

It is noted that today the system of normative-legal acts on counteraction to organized crime is rather branched, which includes norms of constitutional, administrative, criminal, criminal-procedural and other branches of law. Despite the fact that the fight against organized crime is governed by the rules of various branches of law and they are very important, preference among all these rules is given to administrative law to combat organized crime, as they constitute the majority among other legal norms and directly relate to administrative (managerial) activities , on which depends the state policy, strategy, tactics, complexity of legal regulation and other necessary measures to combat organized crime.

Attention is drawn to the obsolescence and low effectiveness of the current Law of Ukraine "On the organizational and legal framework for combating organized crime" and the Criminal Code of Ukraine on the regulation of organized crime in Ukraine.

The adoption of the new Law of Ukraine "On Combating Organized Crime" and the need to intensify a systematic approach to addressing issues of combating organized crime, taking into account trends in organized crime.

Key words: legal support, organized crime.

Постановка проблеми та її актуальність. Незважаючи на реформування правоохоронних органів України, які протидіють організованій злочинності, їхня діяльність усе ще залишається малоефективною, багато в чому наявні проблеми не вирішені. Реформовані органи, на жаль, залишаються такими, що не відповідають міжнародним стандартам захисту прав людини, їм властиві каральна спрямованість, корупційні зв'язки, цілковита залежність від владних осіб та зовнішнього впливу інших держав, дублювання функцій один одного, громіздкий центральний апарат і розбалансована структура на місцях, незадовільне організаційно-правове і кадрове забезпечення їхньої діяльності тощо. Тому важливою передумовою забезпечення ефективної протидії організованій злочинності $є$ створення ефективної (дієвої) нормативно-правової бази, визначення чіткої системи уповноважених суб'єктів здійснення такої протидії, мети і завдань їхньої діяльності, наділення необхідними повноваженнями i компетенцією, створення матеріально-технічних умов, ефективного кадрового забезпечення тощо. Тобто для ефективної протидії організованій злочинності необхідно здійснити цілий комплекс заходів організаційного, правового, економічного, політичного, кадрового тощо характеру. Але варто наголосити, що серед усіх цих заходів основне місце відводиться правовим, які створюють юридичне підґрунтя для ефективної протидії організованій злочинності.

Аналіз останніх досліджень і публікацій. Проблемам ефективності правового регулювання приділялась увага завжди, але єдності в поглядах на зміст, структуру та критерії його ефективності не існує. Наприклад, M.І. Байтін, М.І. Матузов, А.В. Малько ефективність правового регулювання розглядають як співвідношення між результатами правового регулювання та метою, яка поставлена перед ним [1, с. 732]. В.В. Борисов, М.Н. Марченко вважають, що ефективність правових норм - це співвідношення між фактичними або прогнозованими результатами їхньої дії і тими цілями, для досягнення яких вони були ухвалені [2, с. 120]. На думку П.М. Рабіновича, цінність правового регулювання - це його реальна позитивна (корисна) значущість для існування і розвитку особи, соціальних спільнот, груп, об'єднань, для всього суспільства загалом [3, с. 158].

Окремим питанням правового регулювання протидії організованій злочинності присвятили свої праці: Л.І. Аркуша, І.А. Артеменко, О.М. Бандурка, О.Ю. Бусол, В.Л. Грохольський, В.І. Литвиненко, О.М. Литвинов, Н.Е. Міняйло, О.Ю. Шостко й ін. Водночас багато проблем залишаються дотепер невирішеними.

Метою статті $\epsilon$ вивчення й аналіз стану нормативно-правового забезпечення протидії організованій злочинності в Україні, запропонування шляхів його вдосконалення.

Виклад основного матеріалу. Серед правових норм, що мають значення для ефективної протидії організованій злочинності, провідне місце відводиться Конституції України, яка за ст. 8 має найвищу юридичну силу. Закони й інші нормативно-правові акти ухвалюються на основі Конституції України і повинні відповідати їй. У Конституції України визначено державну владу, поділено їі на законодавчу, виконавчу та судову (ст. 6) [4]. У нормах Конституції містяться принципи діяльності влади, права, свободи і гарантії людини і громадянина, правові відносини між суб'єктами й інші норми, що мають велике значення для адміністративно-правового механізму протидії організованій злочинності. Основним із конституційних принципів визначається і повинен діяти принцип верховенства права (ст. 8). Це означає насамперед співвідношення права і держави (органів державної влади, місцевого самоврядування, посадових осіб та ін.), їхню підпорядкованість праву, його пріоритет щодо них.

Адміністративно-правовий механізм протидії організованій злочинності повинен використовуватися шляхом правового визначення конституційних та інших нормативно-правових засад цієї діяльності, іï мети, завдань, стратегії, спеціальних суб'єктів здійснення такої протидії, забезпечення участі всіх державних структур, органів місцевого самоврядування, окремих недержавних установ, громадських формувань і окремих громадян, які можуть бути корисними у протидії організованій злочинності.

Сьогодні система нормативно-правових актів із протидії організованій злочинності $\epsilon$ досить розгалуженою, куди входять норми конституційного, адміністративного, кримінального, кримінально-процесуального й інших галузей права. Незважаючи на те, що протидія організованій злочинності регулюється нормами різних галузей права, вони є досить важливими, перевагу серед усіх цих норм ми віддаємо адміністративно-правовим нормам забезпечення протидії організованій злочинності, оскільки вони становлять більшість серед інших правових норм і безпосередньо стосуються адміністративної (управлінської) діяльності, від якої залежать державна політика, стратегія, тактика, комплексність нормативно-правового регулювання й інші необхідні заходи щодо протидії організованій злочинності.

За період незалежності в Україні фактично єдиним профільним законом із протидії організованій злочинності $\epsilon$ Закон України «Про організаційно-правові основи боротьби з організованою злочинністю» [5]. У ньому вперше було закріплено поняття організованої злочинності; визначено мету боротьби з орга- 
нізованою злочинністю; систему органів, які здійснюють боротьбу з організованою злочинністю; основні напрями боротьби з організованою злочинністю; компетенцію і повноваження спеціальних суб'єктів протидії організованій злочинності; заходи щодо забезпечення боротьби з організованою злочинністю; взаємодію суб'єктів протидії організованій злочинності; інформаційне, фінансове, матеріально-технічне та науково-дослідне забезпечення боротьби з організованою злочинністю; гарантії прав громадян і юридичних осіб під час здійснення заходів боротьби з організованою злочинністю; контроль і нагляд за виконанням законів у сфері боротьби з організованою злочинністю.

Аналіз положень зазначеного Закону дає підстави говорити про його застарілість, розбалансованість норм і їх суперечливість, що створює ситуацію, яка не регулює багато нагальних питань сьогодення із протидії організованій злочинності. Зокрема, у ст. 1 наведено поняття організованої злочинності, під якою розуміється «сукупність злочинів, що вчиняються у зв'язку зі створенням та діяльністю організованих злочинних угруповань» [5]. Як бачимо, законодавець на перше місце ставить сукупність злочинів, що вчиняються у зв'язку зі створенням та діяльністю організованих злочинних угруповань, а не навпаки, - створення організованих злочинних угруповань із метою вчинення злочинів. Крім того, у такій редакції не зрозумілий термін «сукупність злочинів». Виникають питання: яких злочинів, за який період та ін.? На це питання законодавець робить відсилку до Кримінального кодексу (далі - КК) України: «Види та ознаки цих злочинів, а також кримінально-правові заходи щодо осіб, які вчинили такі злочини, встановлюються Кримінальним кодексом України» (п. 2 ст. 1) [5].

Але аналіз КК України також свідчить про неконкретність його норм із протидії організованій злочинності. Так, у п. 3 ст. 28 зазначено: «Злочин визнається вчиненим організованою групою, якщо в його готуванні або вчиненні брали участь декілька осіб (три і більше), які попередньо зорганізувалися у стійке об'єднання для вчинення цього та іншого (інших) злочинів, об'єднаних єдиним планом з розподілом функцій учасників групи, спрямованих на досягнення цього плану, відомого всім учасникам групи» [6]. Як бачимо, у зазначеній нормі містяться положення, які потребують додаткового уточнення, а відтак, $є$ неефективними. Зокрема, що треба розуміти під «стійким об'єднанням», де його критерії, хто визначає, що це стійке чи нестійке об'єднання? Згідно із законодавством, тільки суд, а як визначати це на досудовому розслідувані, відповіді в законодавчих актах на це питання немає.

Далі в зазначеній нормі визначається: «для вчинення цього та іншого (інших) злочинів». Виникає питання, чи досить для кваліфікації організованої групи вчинення одного злочину, чи це повинно бути декілька (серія) учинених злочинів? Наступне: «об'єднаних єдиним планом 3 розподілом функцій учасників групи». А якщо немає чіткого плану і розподілу функцій між учасниками групи, а є факт учинення серії злочинів особами, об'єднаними в одне угруповання за різним ознакам, наприклад, ідеологічним, то це вже не організована злочинна група? Ми бачимо, що норми кримінального законодавства $\epsilon$ нечіткими, неконкретними, потребують додаткових уточнень, з'ясувань, отже, складно застосовувані, що не сприяє ефективній протидії організованій злочинності.

У постанові Пленуму Верховного Суду України від 23 грудня 2005 р. № 13 «Про практику розгляду судами кримінальних справ про злочини, вчинені стійкими злочинними об'єднаннями» зазначається, що з метою однакового і правильного застосування судами законодавства під час розгляду кримінальних справ про злочини, учинені стійкими злочинними об'єднаннями, у розгляді кримінальних справ про злочини, скоєні стійкими злочинними об'єднаннями, необхідно враховувати: норми КК України, у яких визначено особливості кримінальної відповідальності осіб, які вчинили злочини у співучасті (ст. ст. 26-31); ознаки злочину, що вказують на його вчинення організованою групою (ч. 3 ст. 28) або злочинною організацією (ч. 4 ст. 28); положення статей Особливої частини КК України, якими передбачено додаткові ознаки спеціальних видів таких груп чи організацій (ст. ст. 257, $258,260)$. Суди мають досліджувати докази не лише стосовно конкретних злочинів, а й щодо тих ознак, які вказують на їх учинення саме організованою групою чи злочинною організацією, - щодо виду об'єднання, мети його створення і плану злочинної діяльності, тривалості існування, матеріальної бази, кількісного складу, вербування нових членів, структури та ієрархії об'єднання, наявності в нього корупційних зв'язків, існування певних правил поведінки його членів, розподілу між ними функцій тощо. У мотивувальній частині вироку необхідно наводити дані про те, коли саме i протягом якого часу було створено організовану групу чи злочинну організацію, як довго вона функціонувала, відомості про організаторів об'єднання та характер стосунків, які склалися між ними і членами останнього [7]. На наш погляд, доведення “стійкості об'єднання» $€$ досить складним і потребує встановлення багатьох фактів, які лише займають час i дають можливість окремим злочинним формуванням уникнути відповідальності за вчинення злочинів організованою злочинною групою чи злочинною організацією. Виходячи з реальних практичних обставин, після затримання ОЗУ його члени починають давати показання, що не знали про вчинення окремих видів злочинів, що їм про це стало відомо напередодні скоєння, про чіткий розподіл ролей у групі вони теж не знали та багато іншого.

Крім того, під час розгляду багатоепізодних справ судам варто встановлювати, на якому етапі злочинної діяльності об'єднання набуло ознак стійкого, до якого саме виду воно належить, мати на увазі, що нерідко об'єднання зазнає таких змін після вчинення низки злочинів у простих формах співучасті (групою осіб або групою осіб за попередньою змовою) чи трансформується з одного виду в інший (наприклад, декілька організованих груп об'єднуються у злочинну організацію, організована група озброюється і набуває ознак банди) [7]. Таке досудове і судове розслідування із кримінальних справ радше схоже на кримінологічне дослідження, а не на протидію організованій злочинності.

Те саме стосується п. 4 ст. 28 КК України, у якому визначено: «Злочин визнається вчиненим злочинною організацією, якщо він скоєний стійким ієрархічним об'єднанням декількох осіб (п'ять і більше), члени якого або структурні частини якого за попередньою 
змовою зорганізувалися для спільної діяльності з метою безпосереднього вчинення тяжких або особливо тяжких злочинів учасниками цієї організації, або керівництва чи координації злочинної діяльності інших осіб, або забезпечення функціонування як самої злочинної організації, так і інших злочинних груп» [6]. Як бачимо, законодавець чомусь обмежує відповідальність злочинних організацій учиненням тільки тяжких або особливо тяжких злочинів. Із цього випливає, якщо створена злочинна організація вчиняє злочини середньої тяжкості, то така організація не визнається злочинною. Відповідно до ст. 12 КК України, «злочином середньої тяжкості $\epsilon$ злочин, за який передбачене основне покарання у виді штрафу в розмірі не більше десяти тисяч неоподатковуваних мінімумів доходів громадян або позбавлення волі на строк не більше п'яти років» [48].

Отже, наприклад, за вчинення злочинів, кваліфікованих відповідно до ч. 1 ст. 143 КК України «Порушення встановленого законом порядку трансплантації анатомічних матеріалів людини» [6], не можна визнати злочинною організацією, хоча це проблема сьогодення не тільки для України, а й для всього світу.

Далі, положеннями ст. 30 КК України передбачено, що організатор організованої групи чи злочинної організації підлягає кримінальній відповідальності за всі злочини, учинені організованою групою чи злочинною організацією, якщо вони охоплювалися його умислом, а інші учасники організованої групи чи злочинної організації підлягають кримінальній відповідальності за злочини, у підготовці або вчиненні яких вони брали участь, незалежно від тієї ролі, яку виконував у злочині кожен із них [6]. Знову ж Закон захищає організатора організованої групи чи злочинної організації, тому що він відповідає тільки за злочини, учинені організованою групою чи злочинною організацією, якщо вони охоплені його умислом. Отже, якщо в організатора був умисел на вчинення пограбувань і розбійних нападів, а під час їх підготовки і скоєння було вчинено, наприклад, убивство свідка, то організатор за це відповідальності не несе.

Можна сказати, що сьогоднішнє кримінально-правове регулювання, на наш погляд, $є$ малоефективним i дає можливість організаторам організованих груп чи злочинних організацій, членам організованих злочинних формувань уникати кримінальної відповідальності.

Аналіз ст. 3 Закону України «Про організаційно-правові основи боротьби з організованою злочинністю» [5], де визначається мета Закону, свідчить про те, що цей Закон цілковито застарів і майже втратив актуальність. Зокрема, основними завданнями цього Закону є: створення загальних правових і організаційних засад у сфері боротьби з організованою злочинністю, сприяння її попередженню та ліквідації; визначення системи державних органів, що ведуть боротьбу з організованою злочинністю, та їх відносин; встановлення повноважень спеціальних державних органів із боротьби з організованою злочинністю та спеціальних заходів, що здійснюються ними; встановлення обов'язків інших державних органів у сфері боротьби з організованою злочинністю; правове забезпечення фінансових, матеріально-технічних та інших умов, необхідних для боротьби з організованою злочинністю; забезпечення гарантій прав громадян і юридичних осіб під час здійснення заходів боротьби з організованою злочинністю.
Усі ці завдання зазначеного Закону були спрямовані на забезпечення діяльності спеціальних підрозділів із боротьби з організованою злочинністю, їх взаємодію з іншими суб'єктами протидії, надання цими суб'єктами допомоги, насамперед інформації про організовані злочинні формування, спеціальним підрозділам із боротьби з організованою злочинністю тощо. Але сьогодні фактично відсутні спеціальні підрозділи із протидії організованій злочинності, які визначалися цим Законом: спеціальні підрозділи з боротьби з організованою злочинністю Міністерства внутрішніх справ України ліквідовано у 2015 р., а спеціальні підрозділи з боротьби з корупцією та організованою злочинністю Служби безпеки України, відповідно до ухваленого у 2018 р. Закону України «Про національну безпеку» (ст. 19), позбавлені таких функцій. Зокрема, у цьому Законі визначається, що Служба безпеки України є державним органом спеціального призначення із правоохоронними функціями, що гарантує державну безпеку, здійснює з неухильним дотриманням прав і свобод людини і громадянина: 1) протидію розвідувально-підривній діяльності проти України; 2) боротьбу з тероризмом; 3) контррозвідувальний захист державного суверенітету, конституційного ладу і територіальної цілісності, оборонного і науково-технічного потенціалу, кібербезпеки, економічної та інформаційної безпеки держави, об'єктів критичної інфраструктури; 4) охорону державної таємниці [8].

Як бачимо, про протидію організованій злочинності не йдеться, або законодавець організовану злочинність уже не відносить до загроз національної безпеки.

Отже, з вищезазначеного можна зробити висновок, що Закон України «Про організаційно-правові основи боротьби з організованою злочинністю» [5] $є$ застарілим, більшість його норм суперечать іншим законодавчим актам, втратили свою ефективність і не відповідають ситуації сьогодення. Виходячи із цього, пропонується ухвалити новий Закон України «Про протидію організованій злочинності», у якому чітко передбачити:

- стратегічну мету протидії організованій злочинності;

основні напрями протидії організованій злочинності, серед яких: заходи профілактики; запобігання та протидії легалізації (відмиванню) «брудних» коштів; організація правової пропаганди серед населення із протидії організованій злочинності (небезпека для громадян, суспільства, соціально-економічного розвитку, національної безпеки держави тощо); визначення державно-правової політики із протидії організованій злочинності;

суб'єктів протидії організованій злочинності, їхні персоніфіковані завдання, компетенцію, повноваження і відповідальність за стан організованої злочинності;

принципи, форми і методи протидії організованій злочинності;

участь усіх органів державної влади, місцевого самоврядування, державних і недержавних установ (організацій), громадських формувань, окремих громадян та інших суб'єктів у протидії організованій злочинності;

міжнародну взаємодію і співпрацю у протидії організованій злочинності;

матеріально-технічне, інформаційно-аналітичне, фінансове, кадрове, наукове тощо забезпечення протидії організованій злочинності.

Таку пропозицію підтримують 87\% опитаних працівників (керівники органів, підрозділів Національної поліції). 
Висновки. Аналіз вищезазначених законодавчих актів свідчить, що нині існує проблема ефективного регулювання протидії організованій злочинності в Україні. Верховна Рада України як законодавчий орган в останні роки помітно знизила активність із розгляду питань протидії організованій злочинності, про що свідчить застарілий і такий, що не відповідає ситуації сьогодення, Закон України «Про організаційно-правові основи боротьби з організованою злочинністю» та окремі норми Кримінального кодексу України. Тому цілком очевидно, що правотворча робота Верховної Ради України має потребу в активізації системного підходу до вирішення питань із протидії організованій злочинності, з урахуванням тенденцій розвитку організованої злочинності. Адже наскільки буде якісне нормативно-правове забезпечення, настільки й буде ефективною протидія організованій злочинності.

\section{Література}

1. Теория государства и права: курс лекций / М.И. Байтин и др. ; под ред. Н.И. Матузова, А.В. Малько. 2-е изд., перераб. и доп. Москва : Юристъ, 2006. 768 с.

2. Общая теория государства и права. Академический курс : в 3-х т. / В.В. Борисов и др. ; под ред. М.Н. Марченко. 3-е изд. Москва : Норма, 2007. Т. 3 : Государство, право, общество. 712 с.
3. Рабінович П.М. Основи загальної теорії права та держави : навчальний посібник. 5-е вид., зі змінами. Київ : Атіка, 2001. 176 с.

4. Конституція України : Закон від 28 червня 1996 р., із змінами. URL: http://zakon.rada.gov.ua/laws/show/ 254\%D0\%BA/96-\%D0\%B2\%D1\%80 (дата звернення: 20.11.2019).

5. Про організаційно-правові основи боротьби з організованою злочинністю : Закон України від 30 червня 1993 р. № 3341-XII. Відомості Верховної Ради України. 1993. № 35. Ст. 358 (зі змінами).

6. Кримінальний кодекс України : Закон від 5 квітня 2001 р. № 2341-III. Відомості Верховної Ради України. 2001. № № 25-26. Ст. 131 (зі змінами).

7. Про практику розгляду судами кримінальних справ про злочини, вчинені стійкими злочинними об'єднаннями : постанова Пленуму Верховного Суду України від 23 грудня 2005 p. № 13. URL: https://zakon.rada.gov.ua/laws/show/ v0013700-05 (дата звернення: 12.07.2019).

8. Про національну безпеку: Закон України від 21 черв. 2018 року 2469-VIII. Відомості Верховної Ради України. 2018. № 31. Ст. 241 (зі змінами).

Доценко О. С., кандидат юридичних наук, дочент, професор кафедри публічного управління та адміністрування Національної академії внутрішніх справ 